\title{
Information vs Engagement in parliamentary websites - a case study of Brazil and the UK
}

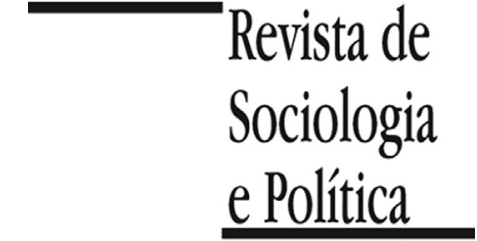

DOI 10.1590/1678-987316245905

\section{Cristiane Brum Bernardes and Cristina Leston Bandeira}

\begin{abstract}
Parliamentary websites have become the main window of parliament to the outside world. More than a gimmick, they are an essential element in the promotion of a relationship between parliament and citizens. This paper develops a comparative analysis of the websites of the lower chambers of the Brazilian and the British parliaments, respectively the Chamber of Deputies and the House of Commons. We structure this analysis around three dimensions: 1) information about the institution; 2) information about parliamentary activity; and 3) tools to promote engagement with the public. The choice of two very different case studies enables us to consider more clearly the specific purposes of these parliamentary websites. We consider in particular if these parliaments' institutional differences affect their websites. The websites' analysis is complemented by semi-structured elite interviews with parliamentary staff who manage the services provided by these websites. Our analysis shows that both websites achieve much higher levels of complexity in the information area than in engagement. But it also shows that the Brazilian parliament website includes far more tools designed for public interaction than its UK counterpart. The indexes and interviews show that both institutions are highly committed to disseminating data and information to citizens. This is seen as a path towards achieving higher accountability and improving knowledge about parliamentary processes and, consequently, improving public image and levels of trust. Whilst there is a strong focus on the provision of information, there is still little evidence of enabling citizen participation in the legislative process. This is partly due to a tension between conceptions of representative democracy and those of participatory democracy. The articulation between these different types of democracy still has a long way to be resolved, although parliaments are slowly introducing participatory tools.
\end{abstract}

KEYWORDS: Internet and Parliament; Parliaments' websites; Political Engagement; Brazil; United Kingdom.

Received in April 15, 2015. Accepted in July 8, 2015.

\section{Introduction ${ }^{1}$}

${ }^{1}$ We thank the anonymous reviewers of the Revista de Sociologia e Política for their comments on this article.
$\mathrm{P}$ arliamentary websites are an important window into parliament. Once closed institutions except for a very few, with the rising of the internet and the spreading of parliamentary websites from the mid 1990s onwards, parliaments are now amongst the most visible of political institutions. And yet they are often amongst the most criticised. At a time when political disengagement is said to be very high (Dalton 2004; Stoker 2006; Hay 2007) getting the institution's communication tools right is of paramount importance.

A discussion has been made over a decade about definition and goals of E-Democracy, as well as actual possibilities of its implementation in diverse political systems. For Trechsel at el., increasing transparency, enhancing participation and improving quality of opinion formation are key objectives of these mechanisms, which are defined as "electronic means of communication that enable/empower citizens in their efforts to hold rulers/politicians accountable for their actions in the public realm" (Trechsel et al., 2003, p.10).

In this article we compare the parliamentary websites of two case studies of institutions that have been particularly criticised the last few years, at the same time as being institutions that have actually introduced considerable reform: the Brazilian Chamber of Deputies and the UK House of Commons. Making use of 
website contents analysis, in-depth elite interviews with parliamentary officials, and documentary analysis, we establish first how these websites were developed to then compare them. We establish the key moments and structures that have led to the development of these sites, to consider if this has an impact on the type of website tools adopted. Our comparative analysis of the websites focuses on three dimensions: 1) static information about the institution, (2) information about parliamentary activity, and (3) opportunities for engagement. We consider the extent to which these are still mainly information repositories rather than engagement tools. We show that these parliamentary websites are still mainly focused on presenting information to the public, although the Brazilian case does also stand out as having far more opportunities for engagement than the UK. But before moving onto the analysis of these case studies, we consider why parliamentary websites matter, still today.

\section{Parliamentary websites as a means to fulfil new media's potential}

The development of digital mechanisms of engagement and interaction with the public has become a key priority for parliaments throughout the world, as many recent studies and reports have demonstrated (Global Centre for ICT 2012; Griffith \& Leston-Bandeira 2012; Inter-Parliamentary Union 2012; Joshi \& Rosenfield, 2013). According to the Inter-Parliamentary Union (IPU), the key objectives of the technology experiments currently being made by parliaments around the globe are to amplify the public's understanding about legislatures and to stimulate citizens' participation in the legislative process (IPU 2012, p.21).

Political support is key in keeping the legitimacy of parliaments and, as consequence, of whole political systems, as demonstrated in the pioneering works of Packenham (1970), Easton (1975) and Mezey (1979). Mezey (1979, p.163) showed back in 1979 that people confront their expectations with their perceptions of legislative actions - meaning that support has a direct link with knowledge and information about legislatures - with resulting higher or lower levels of trust in parliament and parliamentarians. More recently, this has been confirmed by the Audits of Political Engagement (Hansard Society 2004-2014), which have shown that the more knowledge people have on parliament, the more likely they are to be interested. Not only is knowledge (information) about parliament important to maintain a healthy pool of interest for the institution, but also there is evidence showing that the internet plays a key role in ensuring that access to knowledge. In fact, the Connecting with Citizens report shows that three-quarters of the public in the UK gets information about politics from the internet (Hansard Society 2011, p.12), becoming a particularly important source of information for the institution of parliament: $73 \%$ use internet to find out about parliament. Other means of information are less important to find out info about parliament, than they are to find out about politics in general (Hansard Society 2011, pp.13-14).

New media are now a part of everyday life and perceived as having great potential to reduce the distance between people and political representatives. Their specific potential for parliaments is to enhance three basic areas: communication, dissemination and managing of information (Leston-Bandeira 2007), all of which connect with public opinion. However, since political trust is not strictly linked to mere rational evaluations, relying also on symbolic representations produced with irrational and affective answers driven by the citizens to the political institutions (Pitkin 1967; Leston-Bandeira 2012; Van der Meer 2010), a public system of political interaction cannot be sustained by only offering information to the people. It needs to promote activities to engage and implement democratic participation. 
Studies since the 1990s highlight the potential of new media as tools for social engagement (Coleman et al., 1999; Trechsel et al., 2003; Dai 2007; Lilleker \& Jackson 2009), and, as consequence, a way to minimize the problem of low confidence and negative image of legislative institutions. However, the use of new media by political institutions often lag behind and lack in innovation; plus, the internet tends to reinforce the activism from those who already participate in politics (Dai \& Norton 2007; Gibson et al., 2008; Norris 2001).

Nevertheless, Gibson, Lusoli \& Ward (2008, p.562) also state that new media can facilitate an "easier path towards political engagement among those less active or not involved in conventional politics", even if it does also reinforce the activity of those already engaged in social and political issues. The potential of the internet as a medium to enhance democracy is still therefore contested. Recent research has shown that the "digital divide among parliaments is still very strong" (Griffith \& Leston-Bandeira 2012, p.498), even if $95.3 \%$ of parliaments already have websites (Joshi \& Rosenfield 2013, p.534), with only 19\% of legislatures having most representatives also using websites as a way to communicate with citizens (Global Centre for ICT 2012). This does not mean that mechanisms are useless as they are being used nowadays. On the contrary, to provide information and data about public services or actions of representatives is an essential obligation of political agents and institutions and there is a steady strengthening of this provision throughout the world. To ensure the constitutional principle of publicizing public acts, institutions around the world have developed a number of visibility strategies.

Within this general context, parliamentary websites play a particularly important role. Legislatures are often at the core of a political system and their websites have become the main interface with the public. In this study we focus on the parliamentary websites of the lower chambers of two specific parliaments: Brazil and UK. We explore in particular the profile of these websites and the type of information they include, to consider the extent to which they also extent to engagement tools. In particular, we address the following research questions:

1) Which processes/mechanisms of digital participation are on offer on these parliamentary websites?

2) Are there substantial differences between the two parliaments?

3) What institutional structure do these parliaments have to support the development of their websites?

\section{Methodology}

Our study was developed through the coding of elements present in the two parliamentary websites, followed by interviews with parliamentary staff. We focus on the Brazilian Chamber of Deputies and the UK House of Commons, the lower chambers, and therefore directly elected, of these parliaments. We chose these two case studies as interesting cases to contrast. They come from very different types of political system: whilst the UK is a well-established democracy with centuries of democratic history, Brazil is a recently re-democratised country (1988). They also represent contrasting parliamentary (UK) and presidential (Brazil) systems and legislatures elected through a majoritarian electoral system (first-past-the-post, UK) and a proportional electoral system (Brazil). These are however institutions of similar size. The House of Commons is composed by $650 \mathrm{MPs}$, and the Chamber of Deputies by 513 deputies (despite a much larger population). 
The coding of the parliamentary websites follows previous work on parliamentary websites, which have tended to code the existence (or not) of specific items. It was on the basis of this approach that Norris established a ranking of parliaments, according to their online presence (2001). Trechsel et al. (2003) follow a similar approach and divide information provision in five different dimensions: general information, information on MPs, information on committees, information on legislation and information on debates. Leston-Bandeira developed a similar categorization of parliamentary websites, based on different parliamentary functions (2009). Our classification is based on categories presented by Setälä \& Grönlund (2006, p.155) to describe parliamentarian's websites: background information, legislative activity and interactive elements. As a consequence, we have divided the analytical comparison of the digital tools offered in the official websites of the Brazilian Chamber of Deputies and the House of Commons in the UK in three groups:

1) Information about the institution, or general information about parliament and political system (Appendix 1);

2) Information about the parliamentary activity carried out by members (Appendix 2);

3) Tools aimed at promoting interaction between public and legislature (Appendix 3).

This added up to 134 different items to code in each website, such as provision of committee reports or information about parliamentary business. Each item was given a dichotomic code: 1 for when the item was present and 0 when it was absent. This then allowed us to calculate an average mean for each group of tools or items, originating an index of (1) information about the institution, (2) information about parliamentary activity, and (3) engagement tools.

Besides the websites' analysis, carried out in November of 2013, the research also included semi-structured elite interviews with staff responsible for managing the services provided by these websites. We interviewed three officials in the UK in November 2013 and two Brazilian ones in December of the same year.

\section{The support structures of parliamentary websites in the Brazilian and UK parliaments}

The Brazilian official website exists since 2000 in its current format, but the page was first launched in 1997. Its content and tools are managed by a committee of experts and technicians from nine different areas of the House (Portal's Managing Group) created in 2004 to coordinate the usage of ICTs (refs 2010). The majority of professionals involved with the website are from the Technology Department (CENIN) and the Secretariat of Communication (SECOM). The first one includes 394 employees (166 officials and 228 people hired through companies that provide technology services to the Chamber), but approximately 15 deal directly with the website. In Secom, approximately 30 people work directly with the homepage's content, six of them in the Coordination of Institutional Dissemination and the remaining in Agência Câmara, the Chamber's online news agency. ${ }^{2}$ Additionally, approximately 500 people are registered as content providers in all areas of the Chamber, which mean they can add or edit pages in the website. ${ }^{3}$ In 2005 , the website underwent a major redesign and in 2009 the e-Democracia ${ }^{4}$ platform and the profiles in Twitter and Facebook were created.

Considerable effort has been targeted at the web structure inside both Houses in UK Parliament over the past decade. Tinley (2008) stressed, for example, the process of reorganization of the website made since 2005 , when a 
${ }^{4}$ Link to -Democracia platform:

http://edemocracia.camara.gov .br/. The tools offered by e-Democracia are considered in our analysis, as showed in Appendix 3.

5 Official (2013, November), UK House of Commons, interview with the authors. new Web Centre was created with two Strategy Boards: Internet Strategy Board and an Intranet Strategy Board. At present day, the Information Services of House of Commons comprises Public Engagement and Public Information areas. The latter includes Media \& Communications Service and Web \& Intranet Service, the two main responsible sectors for the website. The Web Team has 25 people, between managers, designers, and editors of content for the website and social media. The ICTs in the House of Commons absorbs approximately 200 positions, but this encompasses all types of technology, not just web tools ${ }^{5}$. So although comparisons of staff numbers are often difficult to make due to differences in the way parliaments are organized, there is clearly a much smaller team in the UK Houses of Commons, particularly if we take into account that the web team is actually a joint service supporting both lower and upper chamber.

\section{Information vs Engagement}

${ }^{6}$ Official (2013, December), Brazilian Chamber of Deputies, interview with the authors
The 134 items analysed in each parliamentarian website are divided, as we explain above, in three groups: 1) strategies informing the public about the institution - information about institution; 2) tools disseminating information about the members' activity - information about parliamentary activity; and 3) services promoting interaction between society and parliament - engagement tools. Table 1 shows the number of items included in each category and the index achieved for both websites. The final index is the average of the three indexes.

One first striking result is the high values reached by both websites in the second category: information about parliamentary activity. The Brazilian website reaches 0.95 and the British index is 0.93 . Composed of 44 items, among them committee hearings, committee roll calls and reports or committee speeches and debate, the index shows how the homepages have advanced in dissemination of proceedings in the last few years. It is no coincidence that this group of items has the majority of technological resources applied on them, such as search engines and sophisticated databases. Great part of this information is specifically about the legislative process, as a core activity in both houses. This confirms findings from previous similar analysis: Trechsel et al. (2003, p.21) found that $80.2 \%$ of the information provided by legislatures in Europe was on legislation. This have not changed six years later, when Leston-Bandeira (2009, p.21) showed that legislation was markedly ahead in relation to other parliamentary functions in the information covered on the websites of 15 European legislatures.

As one of the Brazilian interviewees said, "the information about the legislative process is available in a very robust system, any citizens can have all the information they need if they know how to find the data". ${ }^{6}$ The issue sometimes is exactly this: "if they know how to find it". Parliamentary websites are often information heavy, as a consequence of their activity, and the steady increasing complexity and expansion of this same information can make access seem

Table 1 - Websites' Indexes

\begin{tabular}{lccc}
\hline & BR & UK & $\mathbf{N}^{\mathbf{0}}$ of items \\
\hline Information about institution & 0.75455 & 0.7 & 55 \\
Information about parliamentary activity & 0.95455 & 0.93182 & 44 \\
Engagement tools & 0.85714 & 0.51429 & 35 \\
Final Index & 0.85541 & 0.71537 & 134 \\
\hline
\end{tabular}

Source: The authors. 
${ }^{7}$ Official (2013, November), UK House of Commons, interview with the authors.

${ }^{8}$ Official (2013, November), UK House of Commons, interview with the authors.

9 Official (2013, November), UK House of Commons, interview with the authors. opaque. One way to overcome this is by presenting the information through more publicly recognisable outputs and/or actors, rather than processes. As one of the UK Parliament interviewees highlighted, the most popular items in the website are "who's my MP, how do I contact them, who are the members of the House of Lords, what are they doing So, it's about, really positively, it's about the representatives and their role."7

The similarities between the two institutions are also patent in the first category: information about institution. Both indexes are very close to each other: 0.75 for Brazil and 0.7 for the UK. Although not as high, these indexes show that the main information is available online for citizen consultation. The provision of data about the functions and activities of parliament are commonly accepted now and included in homepages almost as mandatory expectation. As one of the Brazilian interviewees stressed, their main priority is to inform the public about parliament, something that both websites have accomplished in an extensive way. Indeed, the provision of information is a key priority for parliaments in general. The World e-Parliament Report (Global Centre for ICT 2012, p.205) shows that over $70 \%$ of parliaments are using the digital technologies to inform or explain, with only just over $50 \%$ also using it to engage people.

However, information is just one step in the path towards transparency. Carman (2009) and Walker (2012) identified lack of information as an obstacle for engagement, or the first level of citizenship. Deepening the argument, Leston-Bandeira (2014) differentiates five steps to public engagement with parliament: 1) information, 2) understanding, 3) identification, 4) participation, and 5) intervention. From this perspective, citizens need a certain amount of information about the institution and MPs to support their ability to act and react in a political world. It is therefore understandable that both institutions have invested so much effort and resources to disseminate basic data about parliamentary activity.

Another reason for publicizing information about parliaments is to improve the reputation and build a better public image for the institution. One interviewee said that "it is expected that a large organization will provide information about itself in a website". However, in their opinion, "a more fundamental reason is the fact that the public trust in politicians and institutions is declining and we feel we need to try to, if not turn it round, at least slow it down". ${ }^{8}$

Parliaments are very vulnerable in terms of image and public satisfaction, in part because of their own characteristics: highly visible, accountable and collective (Leston-Bandeira 2014). The lack of a single identity and their intrinsic conflict are other elements that make difficult to parliament to be "loved" by population. As Hibbing and Theiss-Morse showed (1995), legislatures are bound to be unpopular because they epitomize conflict and are highly public, therefore amplifying the image of conflict. As they state in relation to the US, the "Congress is [...] viewed by the public as an enemy [...] because it is so public" (Hibbing \& Theiss-Morse 1995, p.61). Parliamentary staff are well aware of the difficulties that parliament faces in gaining the public's trust, as shown in our interviews, especially when asked about the main purpose of parliamentary websites: "It is about raising (parliament's) relevance, trying to impress upon people that parliament is relevant to them and trying to show how it is relevant. [...] people are quite distant from the institution. [...] But I would like to think that the website actually gets out and helps to impress people how actually what happens here is relevant to them. And make them have a say in it, and that this shows they can be involved with us." 9

Both of our case studies agree about the need to promote transparency, if not to increment public control over them, at least as a way to improve their image. One problem that emerges, however, is the paradoxical nature of information 
${ }^{10}$ Official (2013, December), Brazilian Chamber of Deputies, interview with the authors.

${ }^{11}$ Official (2013, November), UK House of Commons, interview with the authors.

${ }^{12}$ In Brazil the Chamber of Deputies and the Senate have their own structures and staff, that work in a separately way. about legislatures. At the same time as it should concern all citizens, only a few can actually understand it effectively. As one of the Brazilian interviewees said, the "information about parliament is, sometimes, very technical in terms of language, which means it doesn't favour the popular understanding and participation" ${ }^{10}$. Besides the language problem, one British interviewee pointed out technical challenges that still need addressing such as presenting the information in an open-data format so that users can reuse this data for other purposes: "[...] the real problem we have at the moment is that all of the data that we produced about how MPs work and what parliament does [...] the way it's produced doesn't make it easy to reference. Most of it is not good machinery readable data with lots of rich meta-data. [...] So that's a problem for us. [...] It's the most important thing we do, but it's not easily available to people to take and reuse it." 11

This interviewee also highlighted the importance of providing information about ongoing parliamentary activity as a way to enable citizens' engagement with parliament: "Just saying what the agenda is for Parliament today is probably the most singular important thing we do. 'This is what Parliament is discussing today'. And then what did Parliament talk about yesterday, here is what the MPs have said and here is how people voted. [...] Providing biographical information about members of parliament, providing information about how parliament works, about how people can get involved, so it's a mixture of things."

There are, therefore, great similarities between the two case studies in the first two indexes we have analysed relating to information about the institution and its activity. Not just in terms of what the respective websites include, but also in the staff's reasoning behind the management of this data. As Table 1 shows, the main difference between the Brazilian and the British websites is to be found in the third category: engagement tools. Whilst the UK index is slightly over the centre, at 0.51 , the Brazilian website reaches 0.85 in engagement. With 35 items included, such as comments or suggestions on bills, weblogs from parliamentary bodies, staff or clerks, online chat tools with MPs and e-campaigning, the index demonstrates the availability of a wide portfolio of digital services for citizens' participation and interaction with the institution. The index reflects the existence of a high number of engagement possibilities, but it also reflects real opportunities for deeper engagement where participation takes place over a period of time.

One possible explanation for this variation in the level of engagement tools may lie in the difference between the two polities' political heritage. Whereas staff interviewed in the UK tended to describe the parliament as a traditional institution, predisposed to avoid changes and to preserve old rituals, Brazilian counterparts talked about an institution forged in the last three decades, nearly reinvented with the re-democratization of the country at the end of military dictatorship. Besides this, we should also point out the difference in staff numbers. As demonstrated above, the Brazil Chamber of Deputies has a much larger team dedicated to web communication, than the one in the Houses of Parliament. This is particularly significant if we take into account that the British team has to support two chambers rather than one. Therefore, not only does the UK have a much smaller team, but also this same team has to support the work of nearly three times more members than in its Brazilian counterpart (1427 members (650 +777 ) in contrast to 513$)^{12}$. Engagement requires more than just giving information, it requires a follow-up and reaction; it is not a one-off activity, it is an on-going one. This requires resources, which the Brazilian chamber has clearly provided for more appropriately than its British counterpart.

Besides this, we should also take into account population size and geographical dispersion of Brazilian voters and of MPs. These also provide strong reasons for nurturing the engagement function through digital tools. The Brazilian 
13 For instance, the distance from Brasília to Porto Alegre, in the South, or João Pessoa, in the Northeast, is approximately the same: 2.200 kilometers. Brasilia was built from scratch in the 1960s purposefully in a location that would be equidistant from the extreme points of Brazil and away from main hubs. 14 Official (2013, November), UK House of Commons, interview with the authors.

15 Official (2013, November), UK House of Commons, interview with the authors.

${ }^{16}$ Official (2013, November), UK House of Commons, interview with the authors.

${ }^{17}$ Official (2013, December), Brazilian Chamber of Deputies, interview with the authors.

${ }^{18}$ Official (2013, December), Brazilian Chamber of Deputies, interview with the authors.
Congress is situated in Brasília, a capital very distant geographically from many parts of the country, right in the centre of Brazil in a very isolated area. ${ }^{13}$ In this case, the internet has therefore particular advantages to help facilitate communication with the public and overcome physical barriers. Geographical distance is also an issue in the UK case as recognized by one of our interviewees: parliament "has been here a long time, it seems quite insular, it's very London centric. The team from outreach do a fantastic job going around the country and doing their outreach, which is good, which is brilliant. But that means some acknowledgement for the members of the parliament as well, to go out to the reach and to make it seem less London centric." 14 The UK Parliament has in fact invested considerably on outreach, having a team of regional officers who cover specific regions organizing engagement sessions in those same regions. This is not a simple operation to manage, but it is possible in a country such as the UK. In Brazil this would be far more difficult, particularly considering its poor transport infrastructure. Utilising the parliamentary website to facilitate engagement seems therefore a particularly useful path to follow in the case of Brazil, that is better supported resources wise.

Engagement can play an important role in harnessing legitimacy in parliament. Whilst visibility can make the institution actually more vulnerable, engagement implies some interaction with the public and a two-way process; it can take the citizen from the step of information to understanding. It could, potentially, lead to an improvement of its public image. As one interviewee put it, engagement tools are able to help improve the reputation and image of parliament. In their opinion, parliament can be seen as "distant and old-fashioned" and by engaging with the public it could be seen as "more engaged, less old-fashioned, and more relevant", adding that the public "will feel that parliament matters and it's not distant". 15

Besides this and regardless of whether it actually impacts directly on an improved image, engagement with the public is increasingly becoming an expectation of citizens, as participatory modes of democracy expand. Parliaments are well aware of this, as one of our UK interviewees explained: "it's all about achieving some engagement and all of these tools can actually support representative democracy and make it more effective, and that's why I do my job and why I feel it's working well. I wouldn't do this job in any other organization, I'm really passionate about it. And it ultimately can have a real impact."16

The staff interviewed demonstrated a strong belief that regardless of this being a two-way process, that information is key for a democratic system and that this in itself enables engagement; providing the information being the first step towards engagement. As one of the senior officials interviewed said, "[engagement and information] are tied together in the case of a democratic institution, because it is part of the citizens' right to access information about the democratic process and that in itself is part of engagement". ${ }^{17}$ Since public opinion about parliament tends to be negative, this need for a basic provision of information and tools for engagement are seen as all the more important. If parliament failed to provide citizens with information, "it would have negative consequences on engagement, because people will say 'it's supposed to be democratic, but it doesn't provide us information'". 18

One other issue is the overlap between institution and members. The institution can control and develop its website to some extent, according to specific objectives, which may include some forms of engagement. But it cannot control what its members do, and often it is members who the public knows about and contact. If members do not utilize the tools available and/or do not respond to citizens' requests, there is little the institution can do; although it impacts on the institution's image. As one of our interviewees put it: “One of the biggest prob- 
19 Official (2013, November), UK House of Commons, interview with the authors.

\section{Conclusion}

\footnotetext{
20 Barros, Bernardes \& Rodrigues (2014) have founded a General Index of Engagement of 0.857 for Brazil, 0.314 for Argentina, 0.200 for Uruguay, 0.314 for Paraguay and just 0.085 for Venezuela, which means Brazilian parliamentary website is much more open to engagement than the others.
}

lems we have is that when you open up an opportunity for the public to take part, they are not running to engage with the parliament web team, they want to engage with the members. And if the members are not committed to hearing, listening or actually taking the action based upon public opinion, it can actually have a reverse effect"19. This is a point highlighted by the World e-Parliament Report for parliaments across the world, showing that fewer members are responding to e-mail from the public and that "only $17 \%$ of parliaments have a system for helping members manage and respond to electronic messages from citizens and only one quarter have implemented practices for retaining or managing citizen input received via technology" (Global Centre for ICT 2012, pp.204-205).

As recent studies show, parliaments in Latin America have impressive levels of communication with citizens (Griffith \& Leston-Bandeira 2012). Brazil is no different, being, in fact, identified as the most advanced parliament in engagement tools in that continent and between countries of Mercosur (Perna \& Braga 2012; Barros, Bernardes \& Rodrigues 2014). In a paper presented in 2014, Barros, Bernardes \& Rodrigues (2014) showed that the Brazilian Chamber's website had a far better index regarding tools of engagement than its counterparts in Mercosur ${ }^{20}$. Political culture and these countries' pragmatic needs having recently re-democratised political systems - explain in part the intensive use of new media and, particularly, digital tools of engagement, even in societies with considerable inequalities and digital divide. On the other hand, the stability and long history of the UK parliament can act in an opposite direction, providing for an environment less prone for changes and the development of digital interaction with citizens, as demonstrated by the interviews.

Our analysis of the two parliaments' websites focused on three dimensions: information about the institution, information about activity, and engagement. Our data shows that both websites have a higher focus on information rather than engagement, although the Brazilian one utilises more tools designed for public interaction than its UK counterpart. Several reasons seem to explain this, namely in terms of political culture, with the Brazilian institution being more prone for adaptability, being less traditional. Besides this, it should also be noted that the development of legislative media in Brazil went hand in hand with the unfolding of the re-democratization process of its new 1988 constitution. During the work of the National Constitution Assembly (1986 to 1988), that reinstalled democracy in Brazil, a diary summary of activities was transmitted through commercial radio and television. This set the foundations for the creation of a strong legislative media presence, which was introduced officially in the mid 1990s. From 1997 to 2000, the Chamber installed a TV station, a radio and an online news agency. In this context, the website was a mere continuation towards more transparency and better information about parliament. The development of digital tools and services of information is therefore a logical consequence of parliament's process of democratization.

One other dimension to take into account is these two nations' electoral systems. Whereas the UK parliament is elected through a first-past-the-post system, the Brazilian Chamber of Deputies is elected through an open list proportional representation system. This determines greatly the type of relationship between parliament/MPs and the public. In the UK, individual MPs have great visibility and are the face of the legislative institution. This is much less so in Brazil, where the relationship between representative and citizen is far more complex and indirect. From this perspective, Brazilian parliamentarians have a 
greater need for engagement tools than UK MPs. It is therefore only natural that there is a higher focus on developing engagement in Brazil.

Another issue to consider relates to the low levels of trust in legislatures around the world, and, specifically, in Latin America. It could be argued that legislative institutions could use digital tools in an attempt to improve public confidence, just as parliamentarians could use them for a more direct contact with citizens, without having to rely on mass communication media. But where individual MPs are not necessarily making an effective use of digital tools, as is the case of Brazil, the parliamentary institution may take upon itself to compensate for this and present a complex set of interactive tools. The offer of these tools does not lead to an actual use of the tools by MPs though. And in many cases, one could argue that if anything, the availability of these tools, with low levels of usage, could in fact lead to a reinforcement of poor levels of trust.

The indexes and interviews show that both institutions are highly committed to disseminating data and information to citizens. This is seen as a path towards achieving higher accountability and improving knowledge about parliamentary processes and, consequently, improving public image and levels of trust. Whilst there is a strong focus on the provision of information, there is still little evidence of enabling citizen participation in the legislative process. This is partly due to a tension between conceptions of representative democracy and those of participatory democracy; the articulation between these different types of democracy still has a long way to be resolved, although parliaments are slowly introducing participatory tools. From a liberal-democratic point of view, members of parliament are the representatives of their constituents (voters), something they can achieve through diverse means. Dissemination of information about their mandate is important for public accountability. But increasing levels of direct participation of citizens within the actual parliamentary process can be seen as questioning the representative legitimacy of members of parliament. On the other hand, those promoting tools of participative democracy see it as an important mechanism to enrich representation and the relationship between voters and politicians. As the World e-Parliament Report put it: "While it is good that parliaments are able to use technology to tell citizens about the work of the institution; it is equally important that they use technology to hear what citizens have to say. Perhaps even more so. In this way parliaments can ensure that the use of new communications tools truly engages the public in a productive dialogue that promotes citizen participation in the political process" (Global Centre for ICT, 2012, p.205). Engagement with parliament, hence, is not just a means to improve the public image of institutions, but also a strategy to amend democracy itself.

Cristiane Brum Bernardes (cris.brum@gmail.com) is Ph.D in Political Science by the Instituto de Estudos Sociais e Politicos (IESP) of the Universidade do Estado do Rio de Janeiro (UERJ) and fellow of the Masters in Legislative Power of the Centro de Formação, Treinamento e Aperfeiçoamento da Câmara dos Deputados (CEFOR). Vínculo institucional: Coordenação de Pós-Graduação do Centro de Formação, Treinamento e Aperfeiçoamento da Câmara dos Deputados, CEFOR, Brasília, Distrito Federal, Brasil.

Cristina Leston-Bandeira (C.Leston-Bandeira@leeds.ac.uk) is Ph.D in Political Science by the Uuniversity of Hull and fellow of the School of Politics and International Studies of the University of Leeds (United Kingdom). Vínculo institucional: School of Politics and International Studies, University of Leeds, Leeds, United Kingdom.

\section{References}

Barros, A.T.; Bernardes, C.B. \& Rodrigues, M.R, 2014. Digital Strategies of Political Interaction of Mercosur Parliaments. In 11th Workshop of Parliamentary Scholars and Parliamentarians. Oxford.

Carman, C., 2009. Engaging the Public in the Scottish Parliament's Petitions Process. Edinburgh: Scottish Parliament's Public Petitions Committee. 
Coleman, S.; Taylor, J. \& Donk, W., eds., 1999. Parliament in the Age of Internet. Oxford: Oxford University Press.

Dai, X., 2007. Prospects and Concerns of e-Democracy at European Parliament. Journal of Legislative Studies, 13(3), pp.370-387. DOI: 10.1080/13572330701500789

Dai, X. \& Norton, P., 2007. The Internet and Parliamentary Democracy in Europe. Journal of Legislative Studies, 13(3), pp.342-353. DOI: $10.1093 / \mathrm{pa} / 52.3 .404$

Dalton, R., 2004. Democratic Challenges, Democratic Choices. Oxford: Oxford University Press.

Easton, D., 1975. A Re-Assessment of the Concept of Political Support. British Journal of Political Science, 5(4), pp.435-457. DOI: $10.1017 / \mathrm{s} 0007123400008309$

Gibson, R.; Lusoli, W. \& Ward, S., 2008. The Australian Public and Politics On-Line: Reinforcing or Reinventing Representation? Australian Journal of Political Science, 43(1), pp.111-131. DOI: 10.1080/10361140701842607

Griffith, J. \& Leston-Bandeira, C., 2012. How Are Parliaments Using New Media to Engage with Citizens? The Journal of Legislative Studies, 18(3-4), pp.496-513. DOI: 10.1080/13572334.2012.706058

Joshi, D. \& Rosenfield, E., 2013. MP Transparency, Communication Links and Social Media: A Comparative Assessment of 184 Parliamentary Websites. The Journal of Legislative Studies, 19(4), pp.526-545. DOI: 10.1080/13572334.2013.811940

Hay, C., 2007. Why We Hate Politics. Cambridge, UK: Polity Press.

Hibbing, J. \& Theiss-Morse, E., 1995. Congress as Public Enemy. Cambridge, UK: Cambridge University Press.

Leston-Bandeira, C., 2007. The Impact of the Internet on Parliaments: A Legislative Studies Framework. Parliamentary Affairs, 60(4), pp.655-674. DOI: 10.1093/pa/gsm040

,2009. Parliamentary Functions Portrayed on European Parliaments' Websites. Revista de Sociologia e Política, 17(34), pp.13-27. DOI: 10.1590/s0104-44782009000300003

, 2012. Parliaments' Endless Pursuit of Trust: Re-focusing on Symbolic Representation. The Journal of Legislative Studies, 18(3-4), pp.514-526. DOI: 10.1080/13572334.2012.706059

2014. The Pursuit of Legitimacy as a Key Driver for Public Engagement: The Case of the European Parliament. Parliamentary Affairs, 67(2), pp.437-457. DOI: 10.1093/pa/gss050

Lilleker. D. \& Jackson, N., 2009. Interacting and Representing: Can Web 2.0 Enhance the Roles of an MP? In ESRC Workshop. Lisbon.

Norris, P., 2001. The Digital Divide. Cambridge, UK: Cambridge University Press.

Perna, A., 2010. O lado invisível da participação política: gestão da informação dos mecanismos digitais de participação política nos parlamentos da América Latina, com uma análise do caso da Câmara dos Deputados do Brasil. Dissertation. Master in Science of Information. Brasília: Universidade de Brasília.

Perna, A. \& Braga, S., 2012. The Invisible Side of Political Participation: E-Participation Mechanisms and Information Management in Latin American Parliaments. In M. Sobaci, ed. E-Parliament and ICT-Based Legislation. Hershey: IGI Global.

Pitkin, H., 1967. The Concept of Representation. Berkeley: University of California.

Stoker, G., 2006. Why Politics Matters. Basingstoke: Palgrave MacMillan.

Setälä, M. \& Grönlund, K., 2006. 'Parliamentary Websites: Theoretical and Comparative Perspectives'. Information Polity, 11(2), pp.149-162.

Tinley, D., 2008. The UK Parliament in the Digital Age: A Personal Perspective. In A. Leston-Bandeira \& S. Ward, eds. Parliaments in the Digital Age. Oxford: Oxford Internet Institute.

Trechsel, A.; Kies, R.; Mendez F. \& Schmitter, P., 2003. Evaluation of the Use of New Technologies in Order to Facilitate Democracy. Genève: Université de Genève.

Van der Meer, T., 2010. In What We Trust? A Multi-Level Study into Trust in Parliament as an Evaluation of State Characteristics. International Review of Administrative Sciences, 76(3), pp.517-536. DOI: 10.1177/0020852310372450

Walker, A., 2012. A People's Parliament? Parliamentary Affairs, 65(1), pp. 270-280. DOI: 10.1093/pa/gsr054

\section{Other sources}

Brazil. Website of the Camara Legislativa. Availabe at www.camara.leg.br. Accessed 6 July 2016.

e-Democracia Platform. Available at http://edemocracia.camara.gov.br/. Accessed 6 July 2016.

Global Centre for ICT, 2012. World e-Parliament Report. Available at www.ictparliament.org/wepr2012. Accessed 6 July 2016.

Hansard Society, 2004-2014. Audit(s) of Political Engagement. London: Hansard Society. Available at www.hansardsociety.org.uk/research/public-attitudes/audit-of-political-engagement/\#reports-and-data. Accessed 6 July 2016. 2011. Connecting Citizens to Parliament. London: Hansard Society.

Inter-Parliamentary Union, 2012. Global Parliamentary Report - The changing nature of parliamentary representation. Geneva: Inter-Parliamentary Union.

United Kingdom. Website of the House of Commons in the UK. Available at http://www.parliament.uk. Accessed 6 July 2016. 


\section{Informação x Engajamento em websites parlamentares - um estudo de caso de Brasil e Reino Unido}

\section{Resumo}

Websites parlamentares tornaram-se a principal janela do parlamento para o mundo externo. Mais que uma estratégia publicitária, eles são um elemento essencial na promoção da relação entre parlamentos e cidadãos. Este artigo desenvolve uma análise comparativa dos websites das câmaras baixas dos parlamentos brasileiro e britânico, respectivamente Câmara dos Deputados e Casa dos Comuns. Estruturamos a análise em três dimensões: 1) informação sobre a instituição; 2) informação sobre a atividade parlamentar e (3) ferramentas para promover o engajamento com o público. A escolha de dois casos de estudo tão diferentes permite-nos considerar mais claramente os propósitos específicos desses websites. Consideramos, particularmente, se as diferenças institucionais entre os parlamentos afetam seus websites. A análise dos websites é complementada por entrevistas semiestruturadas com servidores dos parlamentos encarregados de gerenciar os serviços providos pelos websites. Nossa análise mostra que ambos os websites alcançam um alto nível de complexidade nas áreas de informação e engajamento. Porém, mostra ainda que o parlamento brasileiro inclui muito mais ferramentas desenhadas para a interação com o público do que a sua contraparte britânica. Os índices e entrevistas demonstram que ambas as instituições são comprometidas com a disseminação de dados e informações para os cidadãos. Isso é visto com um caminho para ampliar a accountability e melhorar o conhecimento sobre os processos parlamentares e, consequentemente, melhorar a imagem pública e os níveis de confiança nos parlamentos. Enquanto há um forte foco na provisão de informações, ainda há poucas evidências de que os websites são utilizados para possibilitar a participação cidadã no processo legislativo. Este cenário se deve, parcialmente, à tensão entre as concepções de democracia representativa e democracia participativa. A articulação entre estes diferentes tipos de democracia ainda tem um longo caminho para ser resolvida, ainda que os parlamentos estejam lentamente introduzindo as ferramentas participativas.

PALAVRAS-CHAVE: internet e parlamento; websites parlamentares; engajamento político; Brasil; Reino Unido.

This is an Open Access article distributed under the terms of the Creative Commons Attribution Non-Commercial License which permits unrestricted non-commercial use, distribution, and reproduction in any medium provided the original work is properly cited. 


\section{Appendix 1}

Table 1A. Informative elements analysed in the websites

\begin{tabular}{|c|c|c|}
\hline Informative elements analysed in the websites & BR & UK \\
\hline Activities of individual members of parliament & 1 & 1 \\
\hline Annual report(s) of parliament, including plenary and non-plenary bodies & 1 & 1 \\
\hline Basic information concerning the status of a member of parliament (allowances, salary, etc.) & 1 & 1 \\
\hline Biodata and picture of the current and previous Presiding Officers & 1 & 0.5 \\
\hline Biodata and picture of the members of parliament & 1 & 1 \\
\hline Brief description of the Presiding Officer's powers and prerogatives & 1 & 1 \\
\hline Brief history of political system & 1 & 1 \\
\hline Brief history of the parliament & 1 & 1 \\
\hline Budget and staffing of the parliament & 1 & 0 \\
\hline Complete list of non-plenary parliamentary bodies & 1 & 1 \\
\hline Constituency, party affiliation & 1 & 1 \\
\hline Contact information (addresses, telephone and fax numbers, e-mail) of each body & 1 & 1 \\
\hline Contact information for each member of parliament including e-mail address & 1 & 1 \\
\hline Current composition of party groups and coalitions & 1 & 1 \\
\hline Description of representative duties and functions of members & 1 & 1 \\
\hline Description of the activities carried out by the body & 1 & 1 \\
\hline Description of the mandate and terms of reference of each body & 0 & 1 \\
\hline Description of the role and legal responsibilities of the national legislature & 1 & 0 \\
\hline Description of the types and purposes of parliamentary publications & 0 & 1 \\
\hline Diagram of seating arrangements in the plenary and other official meeting rooms & 0 & 0 \\
\hline Diagram/organization chart and functions of the Secretariat of parliament & 1 & 0 \\
\hline Explanation of the election procedure for members & 0 & 1 \\
\hline Explanation of the organization of the website & 1 & 1 \\
\hline General descriptions of jobs in the legislature and a list of current vacancies & 1 & 1 \\
\hline Infographics about legislation & 0 & 0 \\
\hline Information about access to the parliamentary building & 1 & 1 \\
\hline Information about Education programmes & 1 & 1 \\
\hline Information about how and where to obtain parliamentary publications & 1 & 1 \\
\hline Information about parliamentary library, archive, and information services & 1 & 1 \\
\hline Link to each party's website & 1 & 1 \\
\hline Link to personal website of representatives & 0.5 & 1 \\
\hline Link to the electoral commission website & 0 & 0 \\
\hline Links to the websites of each body & 1 & 1 \\
\hline List of all political parties represented in parliament & 1 & 1 \\
\hline List of memberships in global and regional parliamentary assemblies & 0 & 0 \\
\hline List with biodata of previous members of parliament with dates served & 1 & 0 \\
\hline Membership and names of Presiding Officer(s) of each body & 1 & 1 \\
\hline Ministries and other national agencies & 0 & 1 \\
\hline Names of Deputy-Speakers / Vice-Presidents & 1 & 1 \\
\hline National parliaments of other countries & 0 & 0 \\
\hline Other international, regional, and sub-regional parliamentary organizations & 1 & 0 \\
\hline
\end{tabular}


Informative elements analysed in the websites

Other links of interest to parliament as the people's representative body

Overview of the composition and functions of the national parliament

Parliamentary committees and/or commissions

Presidency, Government, Constitutional and Supreme Courts

Results of previous elections

Results of the last elections by party affiliation and constituency

Schedule of current and planned parliamentary activities and events

Selection of links to websites and documents relevant to the work of the body

State/provincial legislatures

Statistical and demographic data (current and historical) on MPs

Statistics on the activities of the current and previous parliaments

Text of the country's Constitution and other founding documents relevant to the work of the parliament

Texts of official press releases of the parliament

Up-to-date list of all current members of parliament

Average

Source: The authors.
BR

UK

1

0

0

0

1

1

1

1

0

0

0

1

1

$\begin{array}{cc}1 & 1 \\ 1 & 1 \\ 0.75455 & 0.7\end{array}$




\section{Appendix 2}

Table 2A. Informative aspects about Legislation analysed in the websites

\begin{tabular}{|c|c|c|}
\hline Informative aspects about Legislation analysed in the websites & $\mathbf{B R}$ & UK \\
\hline Amendments (Committee) & 1 & 1 \\
\hline Amendments (Plenary) & 1 & 1 \\
\hline Archive of broadcast or webcast meetings, events, and programs & 1 & 1 \\
\hline Audio or video archive of committee meetings & 1 & 1 \\
\hline Audio or video archive of plenary meetings & 1 & 1 \\
\hline Audio or video broadcast of committee meetings & 1 & 1 \\
\hline Audio or video broadcast of plenary meetings & 1 & 1 \\
\hline Audio or video webcast of committee meetings & 1 & 1 \\
\hline Audio or video webcast of plenary meetings & 1 & 1 \\
\hline Chart or diagram showing how the business of parliament is conducted & 1 & 1 \\
\hline Committee hearings & 1 & 1 \\
\hline Committees roll calls and reports & 1 & 1 \\
\hline Committees speeches and debate & 1 & 1 \\
\hline $\begin{array}{l}\text { Database of documentation related to budget/public financing from the current and previous } \\
\text { years }\end{array}$ & 1 & 1 \\
\hline Database of documentation related to oversight activities from the current and previous years & 1 & 1 \\
\hline Database of pictures of events & 1 & 1 \\
\hline Documentation from plenary sessions from previous years & 1 & 1 \\
\hline Documentation of non-plenary bodies from previous years & 1 & 1 \\
\hline Documentation produced by non-plenary bodies & 1 & 1 \\
\hline Explanation of oversight responsibilities and the activities of oversight bodies & 1 & 1 \\
\hline Explanation of proposed budget/public financing & 1 & 0 \\
\hline Explanation of the budget and public financing processes & 1 & 1 \\
\hline Explanation of the legislative process & 1 & 1 \\
\hline Explanations of actions & 0 & 1 \\
\hline Explanations of bills & 1 & 1 \\
\hline Full text of the Standing Orders, Rules of Procedure or similar rule-setting documents & 1 & 1 \\
\hline Glossary of parliamentary terms and procedures & 1 & 1 \\
\hline Government positions or statements & 1 & 1 \\
\hline Links to documentation related to proposed legislation & 1 & 1 \\
\hline Membership of committees & 1 & 1 \\
\hline News stories about legislative process & 1 & 1 \\
\hline Oversight documentation from current year & 1 & 1 \\
\hline Oversight documentation from previous years & 1 & 1 \\
\hline Overview of parliamentary procedure and routine order of business & 1 & 1 \\
\hline Plenary speeches and debate & 1 & 1 \\
\hline Plenary votes and roll calls & 1 & 1 \\
\hline Search engine for all parliamentary information & 1 & 1 \\
\hline Status of parliamentary review of the proposed budget/public financing activities & 1 & 0 \\
\hline Summary and status of oversight activities & 0 & 0 \\
\hline Text and actions taken on all enacted legislation & 1 & 1 \\
\hline Text of proposed legislation & 1 & 1 \\
\hline
\end{tabular}


Informative aspects about Legislation analysed in the websites

Text of proposed legislation from previous years

Today's business schedule in the parliament

Websites of non-plenary bodies

Average

Source: The authors.
BR

1

1

1

1

0.95454
UK

1

1

1 


\section{Appendix 3}

Table 3A. Tools of interaction and engagement

\begin{tabular}{|c|c|c|}
\hline Tools of interaction and engagement & BR & UK \\
\hline Alerting services for changes to the text of legislation & 1 & 1 \\
\hline Alerting services for committee activities & 1 & 1 \\
\hline Alerting services for introduction of, and changes to, the status of legislation & 1 & 1 \\
\hline Alerting services for members' activities & 1 & 1 \\
\hline Alerting services for oversight and scrutiny activities & 1 & 0 \\
\hline Alerting services for plenary activities & 1 & 1 \\
\hline Bills analysis by the public incorporated in the legislative process & 1 & 0 \\
\hline Bills comments & 1 & 1 \\
\hline Bills suggestions & 1 & 0 \\
\hline Blogs from Parliamentary Bodies & 1 & 0 \\
\hline Blogs from Staff/ Clerks Bodies & 1 & 0 \\
\hline Chats with MPs & 1 & 0 \\
\hline Chats with staff & 0 & 0 \\
\hline E-Campaingning & 0 & 0 \\
\hline Educational activities & 1 & 1 \\
\hline Email for MPs contact & 1 & 1 \\
\hline Email for staff contact & 1 & 1 \\
\hline Email for Parliamentary Bodies contact & 1 & 1 \\
\hline E-Petitions & 0 & 0 \\
\hline Foruns & 0 & 0 \\
\hline Games & 1 & 1 \\
\hline Guestbook & 1 & 0 \\
\hline Links to Social Media & 1 & 1 \\
\hline News comments & 1 & 0 \\
\hline Newsletter & 1 & 1 \\
\hline Online meetings & 1 & 0 \\
\hline Suggestions of issues for debate & 1 & 0 \\
\hline Suggestions of procedures & 0 & 0 \\
\hline Surveys & 1 & 0 \\
\hline Surveys results & 1 & 0 \\
\hline Use of facebook & 1 & 1 \\
\hline Use of other social media & 1 & 1 \\
\hline Use of twitter & 1 & 1 \\
\hline Use of Youtube & 1 & 1 \\
\hline Virtual 'Guided tour' of the parliamentary building & 1 & 1 \\
\hline Average & 0.857143 & 0.514286 \\
\hline
\end{tabular}

Source: The authors. 


\section{ERRATA}

No artigo Information vs Engagement in parliamentary websites - a case study of Brazil and the UK, DOI 10.1590/1678-987316245905, publicado na Revista de Sociologia e Política Vol. 24 N. 59, p. 91-107, constatou-se o seguinte erro:

\section{Página 91}

Onde se lê

Kindgom

Leia-se

Kingdom 